\title{
EVALUATION OF RISK FACTORS IN SUPEROBESE PATIENTS SUBMITTED TO CONVENTIONAL FOBI-CAPELLA SURGERY
}

\author{
Euclides Dias MARTINS-FILHO' ${ }^{1}$, José Bezerra CÂMARA-NETO', \\ Álvaro Antônio Bandeira FERRAZ2 , Melânia AMORIM ${ }^{3}$ and Edmundo Machado FERRAZ ${ }^{4}$
}

\begin{abstract}
Background - Obesity is one of the world's greatest health problems. The Roux-en-Y gastric bypass is the gold standard treatment for severe obesity. Surgery in obese patients has an acceptable level of morbidity and mortality. The superobese patient, a subcategory of severe obese patients with a high surgical risk has not yet been analyzed as a group. Methods - A retrospective and prospective cohort study was conducted enrolling 135 patients submitted to Roux-en-Y gastric bypass for treatment of severe obesity at the "Hospital das Clínicas", Federal University of Pernambuco, Recife, PE, Brazil, between November 1997 and September 2003. The independent variables were possible risk factors of adverse outcomes: age, gender, weight, body mass index, diabetes, hypertension, hypercholesterolemia, sleep apnea, cardiopathy/coronariopathy, pneumopathy or any other co-morbidity. The dependent variables were major complications, minor complications and death. Results - Diabetes $(R R=1.6$ and $C I=1.02-2.40)$ and sleep apnea $(R R=1.8$ and $C I=1.18-2.64)$ were associated to minor complications. Cardiopathy/coronariopathy were associated with major complications $(\mathrm{RR}=5.42$ and $\mathrm{CI}=1.22-2.40)$ and death $(\mathrm{RR}=16.25$ and $\mathrm{CI}=3.00-87.95) . \mathrm{BMI} \geq 55 \mathrm{~kg} / \mathrm{m}^{2}$ was associated with minor complications $(\mathrm{RR}=1.58$ and $\mathrm{CI}=1.04-2.40)$, major complications $(\mathrm{RR}=3.17$ and $\mathrm{CI}=1.03-9.80)$ and death $(P=0.007)$. After logistic regression, the body mass index $\geq 55 \mathrm{~kg} / \mathrm{m}^{2}$ remained as a strong risk factor of death $(\mathrm{OR}=3.6$ and $\mathrm{CI}=1.05-12.32)$. Conclusions - The body mass index $\geq 55 \mathrm{~kg} / \mathrm{m}^{2}$ was the main risk factor for severe complications and death. Other risk factors affecting the outcome were diabetes, obstructive sleep apnea and cardiopathy/coronariopathy.

HEADINGS - Obesity, morbid. Bariatric surgery. Risk factors. Postoperative complications.
\end{abstract}

\section{INTRODUCTION}

Obesity is a public health problem throughout the world and the most common nutritional problem in the United States of America, involving large sums of money. Sixty-eight billion dollars are spent each year with an additional 30 billion going to weight reduction programs and 100 billion dollars per year for special dietary preparations, i.e., a figure similar to that of the total amount spent on cancer. Obesity is responsible for $2 \%$ to $8 \%$ of total health costs in Western countries ${ }^{(20)}$.

The term morbid obesity with body mass index (BMI) $>40 \mathrm{~kg} / \mathrm{m}^{2}$, was coined in 1963 by the surgeon J. Howard Payne in order to characterize potential complications due to obesity and force health insurance companies to pay for the procedure ${ }^{(19)}$. The current term with wide acceptance is that of severe or superobesity, preferable to the former "morbid obesity"(26).

There is much evidence for the increase in morbidity and mortality of those with severe obesity, both men and women $^{(32)}$. The co-morbidities that affect severely obese people were listed at the National Institutes of Health (NIH) Consensus Conference in $1985^{(25)}$. These comorbidities include systemic arterial hypertension (SAH), diabetes mellitus (DM), hypertrophic cardiomyopathy, hyperlipidemia, pulmonary embolism (PE), determined neoplasms, hepatic steatosis, cholelithiasis, degenerative arthropathy, hypoventilation, obstructive sleep apnea (OSA) and psychosocial problems.

Currently it is believed that 1.7 billion people in the world suffer from being overweight and obese, resulting in a substantial impact on health systems and causes some authors to coin the term "globesity"(9). It is currently estimated that the number of deaths per year in the USA and Europe related to obesity is around 300,000 and 220,000 , respectively ${ }^{(1,9)}$. The mortality rate for men between the ages of 25-40 carriers of severe obesity, is 12 times that for men of normal weight ${ }^{(8)}$. A high incidence of co-morbidities and premature deaths occur most often in the severe obese group ${ }^{(10)}$.

There is strong evidence that weight reduction leads to a decrease in risks, health costs and an improvement

Division of Bariatric Surgery - Department of General Surgery - Federal University of Pernambuco (UFPE).

'Post-Graduation Course in Surgery, Federal University of Pernambuco (UFPE); ${ }^{2}$ Basis of Surgical Techniques of the General Surgery Department - UFPE; ${ }^{\prime \prime}$ Instituto Materno-Infantil" of Pernambuco; “Department of Abdominal Surgery - UFPE, Recife, PE, Brazil.

Correspondence: Dr. Euclides Dias Martins Filho - Rua Vitoriano Palhares, 255 - apt. 1001 - Torre - 50710-190 - Recife, PE, Brazil. Email: euclides_martins@yahoo.com.br 
in the quality of life ${ }^{(31,32)}$. Clinical treatment related to long-term weight loss is inefficient, failing to maintain weight loss over a long period of time, in such a way that $90 \%$ to $95 \%$ of patients regain the weight $\operatorname{lost}^{(29)}$. On the other hand, bariatric surgery emerges as an option capable of causing sustainable weight loss and reduction of co-morbidities. When gastroplasty is associated with gastrojejunal bypass the procedure is denominated Rouxen-Y gastric (RYG) bypass ${ }^{(34)}$. Currently this bariatric procedure is the most widely used and corresponds to $80 \%$ of all obesity surgeries carried out in the USA. Gastroplasty with RYG bypass was initially described by MASON et al. ${ }^{(22)}$, in 1969, has suffered various modifications throughout the years and was finally perfected by Fobi and Capella ${ }^{(5,15)}$.

Gastrointestinal surgery in a superobese patient is technically difficult, because of exposure limitation, hepatomegaly due to steatosis, increase in omental and mesenteric fat, besides short mesenterium. The high incidence of surgical complications in obese patients is already known ${ }^{(27)}$. However, increased experience with gastric surgery for severe obesity has gradually reduced these risks to acceptable values.

Current mortality is around $1 \%$ with immediate postoperative complication rates between $3 \%$ to $20 \%$, as the most serious complications occur within the first 30 days ${ }^{(14)}$. The frequency of serious complications with leakage of the anastomosis and peritonitis vary between $0.5 \%$ to $3.9 \%$, appearing more frequently in those patients of greater age and with an android fat distribution ${ }^{(6,22)}$. With greater experience in surgical treatment of obese patients, it has become evident that severe obesity refers to a distinctive group. Apart from severe obesity itself, there is a subgroup of patients with high surgical risks: the superobese.

Superobesity is defined as the presence of BMI equal to or more than $50 \mathrm{~kg} / \mathrm{m}^{2}$ or $225 \%$ above the ideal body weight, a concept introduced into literature by Mason ${ }^{(2,4)}$. The number of superobese patients has been increasing over the last decades, presenting a unique physiopathology and behavior, which influences the prognosis ${ }^{(19)}$. There are very few studies in literature that evaluate the superobese or their surgical results in isolation.

For bariatric surgeons it is important to consider another class of obese, given that the post-operative evolution of this group is singular, presenting a higher incidence of co-morbidities and complications. Immediate post-operative care of these patients requires precautions and adequate equipment. The following measures are fundamental: stop smoking, weight loss of $10 \%$ to $15 \%$, improvement in pulmonary restriction, glycemic control, control of blood pressure, pre-operative transport planning, anesthetic techniques, peri-operative surgical exposure (adequate instruments) and special post-operative care (prolonged mechanical ventilation) including measures to ensure comfort and hygiene after the procedure.

A high surgical risk caused by co-morbidities determines the need for special care. Worried about this additional risk, FERRAZ et al. ${ }^{(12)}$, in 2002, compared co-morbidities and postoperative complications of the superobese with those of the operated severe obese and demonstrated that the frequency was higher in the former group, creating the table of results from Recife, PE, Brazil. This score, by using a points system, quantifies pre-operatively the chances of occurrence of severe complications and death.

In the majority of casuistics, we verify acceptable complications and mortality rates; however there exists a population of superobese with greater prevalence for co-morbidities and with increased possible risk for post-operative morbi-mortality. Thus, the need to identify risk factors predictive of post-operative complications and death in superobese patients submitted to surgical treatment for obesity is evident.

\section{METHODS}

The study was carried out in the General Surgery Division - "Hospital das Clínicas" of the Federal University of Pernambuco (HC-UFPE). A group of study patients was submitted to preoperative evaluation, surgery and post-operative accompaniment in the general surgery department of HC-UFPE. They also counted on the support of the intensive therapy unit (ITU) in this hospital. Another group came from the private clinic of two surgeons on the staff of HC-UFPE, accompanied in their consulting rooms and private hospitals in the city of Recife. One hundred and thirty-five superobese patients, submitted to RYG bypass - Fobi-Capella procedure, were evaluated in a period from November 1997 to September 2003.

An ambidirectional (prospective and retrospective) cohort study was carried out in which patients submitted to Fobi-Capella procedure in a period from November 1997 to September 2003 were accompanied from surgery to the 30th day of the post-operative period. The retrospective stage extended from of November 1997 to February 2003, whilst the prospective stage was from February to September 2003.

The population cohort study included subjects who had in common submission to RYG bypass and who were accompanied over a period of time (longitudinal study). This kind of study permits verification, during accompaniment of various outcomes (amongst which are complications and deaths), also permitting the identification of risk factors (exposure).

Analyzing the characteristics of these patients, the median age was 38.1 varying from 16 to 68 years. The percentage of patients with an age greater than 40 was $45.9 \%$. There was a predominance of the male gender $(52.6 \%)$. The patients' weights varied from 110 to $268 \mathrm{~kg}$, with a median of $159.7 \mathrm{~kg}$. The percentage of patients with weight equal to or greater than $160 \mathrm{~kg}$ was $45.2 \%$. The median BMI 56.7 (varying from 50 to 89.5 ). In addition, $56 \%$ of the patients were found to have a BMI higher than 55.

The sample size calculation was carried out using the EpiInfo 6.04d STATCALC program, through the following formula for cohort studies:

$\left.\left.\mathrm{n}=\mathrm{n}^{\prime} / 4 *\left[1+\sqrt{ } 1+2(\mathrm{c}+1) /\left(\mathrm{n}^{\prime} \mathrm{c} \mid \mathrm{p} 2-\mathrm{p} 1\right) \mid\right)\right)\right]^{2}$

with:

$\mathrm{n}^{\prime}=\frac{\left[\mathrm{Z}(1-\alpha / 2) \sqrt{ }(\mathrm{c}+1) \mathrm{p}(1-\mathrm{p})+\mathrm{Z}(1-\beta) \sqrt{ } \mathrm{c}^{*} \mathrm{p} 1(1-\mathrm{p} 1)+\mathrm{p} 2(1-\mathrm{p} 2)\right]^{2}}{\mathrm{c}^{*}(\mathrm{p} 2-\mathrm{p} 1)^{2}}$
$\mathrm{p}=(\mathrm{p} 1+\mathrm{cp} 2) /(1+\mathrm{c})$
$\mathrm{p} 1:$ frequency in group 1


$\mathrm{p} 2$ : frequency in group 2

c : group ratio 1: group 2

$\mathrm{Z} \alpha$ : alpha error

$Z(1-\beta)$ : power

Predicting around $25 \%$ frequency of complications in patients with BMI $<55$ and twice the risk ( $50 \%$ frequency) in patients with BMI $>55$, with a power of $80 \%$ and an alpha error of $5 \%, 130$ patients would be needed in order to demonstrate this difference.

All patients classified as superobese submitted to RYG bypass during the period of the study were included. After patient identification a register was completed with the data of the patient and medical chart. After discharge, in the case of evolution and complication data being incomplete or data being absent on the medical chart, contact was made by telephone with the patients in order to complete the register.

Analysis variants were classified as dependent (moderate post-operative complications, serious post-operative complications and death) and independent (age, gender, weight, BMI, diabetes, hypertension, hypercholesterolemia, obstructive sleep apnea, cardiopathy, coronariopathy, pneumopathy and any other co-morbidity).

Patients were submitted to complete pre-operative evaluation and then operated. After surgery, the patients remained in the ITU or Intensive Care Unit for 12 hours. Respiratory physiotherapy twice a day and early walking stimulus were part of the post-operative routine. Feeding was initiated around the 2 nd post-operative day (POD) and discharge generally occurred on the 4 th POD. Post-operative accompaniment was carried out in the out-patients department on the 15th POD, at which time surgical wound stitches were removed and on the 30th POD weight, complaints and symptoms were noted.

Data analysis was carried out using the same Epi-Info 2003 program. For the continual numerical variables, age, weight and BMI, were used like measures of central tendency and dispersion, the medium and the standard-deviation. In treating a sample of 100 patients or more, the normality of data (central median regression theory) may be assumed. Frequency distribution tables were constructed for the variable categories.

In order to test the association between post-operative complications (dependent variable) and the biological and clinical pre-operative variables (independent variables) the chi-squared association test was used. The Fisher exact test was also used when necessary (when one of the expected values is less than five) The relative risk was measured using risk ratio (RR) and the confidence interval 95\% (CI 95\%) for each one of the variables associated to the presence of post-operative complications, defining for the reference category (without complications) the risk norm of 1.0. A multiple logistic regression analysis was carried out in order to identify the predictive variables (independents) more strongly associated with serious post-operative complications and death (dependent variable).
In this stage of analysis the variables followed a binary code $(1=$ yes; $0=$ no). In the final model the variables that persisted associated with outcome (presence of post-operative complications) to a significance level of $5 \%$ were selected.

\section{RESULTS}

In relation to the presence of co-morbidities in the sample of patients we discovered that hypertension was most frequent, being present in $67.1 \%$ of cases. Other common diseases in these patients were pneumopathies $(32.6 \%)$, diabetes mellitus $(25.2 \%)$, obstructive sleep apnea $(24.4 \%)$, arthropathy $(14.1 \%)$, gastritis $(14.8 \%)$ and hypercholesterolemia $(14.1 \%)$. Other co-morbidities found in a less frequent form were cholelithiasis observed in $12.5 \%$ of cases, lymphangitis of inferior limbs in $8.1 \%$ of patients, and esophagitis/Barrett's esophagus/hiatus hernia present in $9.6 \%$ of cases. Three sample patients presented umbilical hernia which corresponds to $2.2 \%$. Coronariopathy, depression and incisional hernia were described in two patients in each category $(1.5 \%)$. In the casuistic there was one case of nephrolithiasis, one of prostatic hypertrophy, one of hypogonadism, one of lupus and one of anexial tumor $(0.7 \%)$. It is important to call attention to the fact that a patient may have more than one co-morbidity. Considering the presence of anyone of the co-morbidities, $88.9 \%$ of the sample presented co-morbidity associated with obesity (Table 1).

TABLE 1. Frequency distribution of co-morbidities in 135 superobese patients submitted to Fobi-Capella gastric bypass surgery

\begin{tabular}{|c|c|c|}
\hline Co-morbidities & $\mathrm{n}$ & $\%$ \\
\hline Diabetes & 34 & 25.2 \\
\hline Hypertension & 91 & 67.1 \\
\hline Hypercholesterolemia & 19 & 14.1 \\
\hline Obstructive sleep apnea & 33 & 24.4 \\
\hline Cardiopathy/coronariopathy & 02 & 1.50 \\
\hline Pneumopathy & 44 & 32.6 \\
\hline Lymphangitis of inferior members & 11 & 8.1 \\
\hline Arthropathy & 31 & 22.9 \\
\hline Thyroid disease & 04 & 2.9 \\
\hline Esophagitis/Barrett/Hiatus hernia & 13 & 9.6 \\
\hline Gastritis & 20 & 14.8 \\
\hline Umbilical hernia & 03 & 2.2 \\
\hline Incisional hernia & 02 & 1.4 \\
\hline Nephrolithiasis & 01 & 0.7 \\
\hline Prostatic hypertrophy & 01 & 0.7 \\
\hline Cholelithiasis & 17 & 12.5 \\
\hline Hypogonadism & 01 & 0.7 \\
\hline Depression & 02 & 1.4 \\
\hline Lupus & 01 & 0.7 \\
\hline Anexial tumor & 01 & 0.7 \\
\hline Any co-morbidity* & 120 & 88.9 \\
\hline
\end{tabular}

A patient may have one or more co-morbidities

Source: Research UFPE 
Amongst the 135 patients the presence of any type of complication was observed in 61 (45.2\%). The complications considered to be severe occurred in $13(9.6 \%)$ and moderate ones in $53(39.3 \%)$ of cases. A patient may have presented more than one complication (Table 2).

TABLE 2. Frequency distribution of post-operative complications in 135 superobese patients submitted to Fobi-Capella gastric bypass surgery

\begin{tabular}{lcc}
\hline Complication* $^{*}$ & $\mathbf{n}$ & $\%$ \\
\hline Severe Complications & 13 & 9.6 \\
Peritonitis & 04 & 3.0 \\
Cavity abscess & 02 & 1.5 \\
Anastomosis leakage & 01 & 0.7 \\
Evisceration & 01 & 0.7 \\
Gastric distension & 02 & 1.5 \\
Relaparotomy & 06 & 4.4 \\
Pulmonary embolism & 03 & 2.2 \\
Acute myocardial infarct & 01 & 0.7 \\
Death & 05 & 3.7 \\
Moderate complications & 53 & 39.3 \\
Seroma & 40 & 29.6 \\
Surgical wound infection & 11 & 8.1 \\
Urinary infection & 01 & 0.7 \\
Respiratory infection & 03 & 2.2 \\
Athelectasy & 07 & 5.2 \\
Pleural stroke & 01 & 0.7 \\
Deep vein thrombosis & 01 & 0.7 \\
Hemotransfusion & 01 & 0.7 \\
$*$ Any complication & 61 & 45.2 \\
\hline
\end{tabular}

Each patient may have one or more complications

Source: Research UFPE

Analyzing initially the serious complications, relaparotomy was necessary in six (4.4\%) of the patients. Four (3.0\%) of patients presented peritonitis and two $(1.5 \%)$ cavity abscesses. Pulmonary embolism occurred in three $(2.2 \%)$ patients and acute gastric distension in two cases $(1.5 \%)$. There was a case of leakage of the anastomosis, an acute myocardial infarct and an evisceration. The frequency of death was five (3.7\%) (Table 2).

The most frequent moderate complication was seroma, occurring in $40(29.6 \%)$ of patients. Around $11(8.1 \%)$ of patients had wound infection, $7(5.2 \%)$ had athelectasy and $2.2 \%$ respiratory infection (Table 2 ).

Analyzing the biological characteristics of the patients and their association with the presence of moderate post-operative complications, it was observed that BMI greater than 55 was associated with greater risk of complications $(\mathrm{RR}=1.58)$. There was no association with age greater than 40, gender, weight above $160 \mathrm{~kg}$ in relation to the presence of moderate post-operative complications (Table 3 ).

TABLE 3. Risk of moderate post-operative complications according to biological characteristics in 135 superobese patients submitted to Fobi-Capella gastric bypass surgery

\begin{tabular}{lcccc}
\hline Characteristic & With complication & Without complication & RR & CI 95\% \\
\hline Age & & & & \\
$\quad \geq 40$ years & $28(44.4 \%)$ & $35(55.6 \%)$ & 1,28 & $0,84-1,95$ \\
$\quad<40$ years & $25(34.7 \%)$ & $47(65.3 \%)$ & 1,00 & \\
$\begin{array}{l}\text { Gender } \\
\quad \text { Male }\end{array}$ & $31(43.7 \%)$ & $40(56.3 \%)$ & 1,27 & $0,83-1,95$ \\
$\quad$ Female & $22(34.4 \%)$ & $42(65.6 \%)$ & 1,00 & \\
Weight & & & & \\
$\geq 160 \mathrm{~kg}$ & $23(37.7 \%)$ & $38(62.3 \%)$ & 0,93 & $0,61-1,42$ \\
$<160 \mathrm{~kg}$ & $30(40.5 \%)$ & $44(59.5 \%)$ & 1,00 & \\
BMI & & & & \\
$\geq 55$ & $28(50.0 \%)$ & $28(50.0 \%)$ & 1,58 & $1,04-2,40$ \\
$<55$ & $25(31.6 \%)$ & $54(68.4 \%)$ & 1,00 & \\
\hline
\end{tabular}

Source: Research UFPE
In relation to moderate post-operative complications according to co-morbidities, diabetes mellitus and obstructive sleep apnea were associated with greater risk $(\mathrm{RR}=1.6$ and 1.80 , respectively). There was no association with hypertension, hypercholesterolemia and pneumopathy with the presence of moderate complications. When the presence of any co-morbidity was evaluated, there was no greater risk of moderate post-operative complications (Table 4).

TABLE 4. Risk of moderate post-operative complications according to the presence of co-morbidities in 135 superobese patients submitted to Fobi-Capella gastric bypass surgery

\begin{tabular}{lcccc}
\hline Characteristic & With complication & Without complication & RR & CI 95\% \\
\hline Diabetes & $18(52.9 \%)$ & $16(47.1 \%)$ & 1,60 & $1,02-2,40$ \\
$\quad$ Yes & $34(34.0 \%)$ & $66(66.0 \%)$ & 1,00 & \\
$\quad$ No & $37(40.7 \%)$ & $54(59.3 \%)$ & 1,17 & $0,72-1,88$ \\
Hypertension & $15(34.9 \%)$ & $28(65.1 \%)$ & 1,00 & \\
$\quad$ Yes & & & & \\
No & $07(36.8 \%)$ & $12(63.2 \%)$ & 0,94 & $0,50-1,77$ \\
Hypercholesterolemia & $45(39.1 \%)$ & $70(60.9 \%)$ & 1,00 & \\
$\quad$ Yes & & & & \\
No & $0(0.0 \%)$ & $02(100.0 \%)$ & 0,0 & - \\
Cardio/coronariopathy & $50(38.5 \%)$ & $80(61.5 \%)$ & 1,00 & \\
$\quad$ Yes & & & & \\
No & $13(29.5 \%)$ & $31(70.5 \%)$ & 0,70 & $0,42-1,18$ \\
Pneumopathy & $37(42.0 \%)$ & $51(58.0 \%)$ & 1,00 & \\
$\quad$ Yes & & & & \\
No & $19(57.6 \%)$ & $14(42.4 \%)$ & 1,80 & $1,18-2,64$ \\
Sleep apnea & $33(32.7 \%)$ & $68(67.3 \%)$ & 1,00 & \\
$\quad$ Yes & & & & \\
No & $48(40.0 \%)$ & $72(60.0 \%)$ & 1,20 & $0,60-2,54$ \\
Any co-morbidity & $05(33.3 \%)$ & $10(66.7 \%)$ & 1,00 & \\
$\quad$ Yes & & & & \\
No & & & & \\
\hline
\end{tabular}

Source: Research UFPE

When the characteristics of the patients were evaluated in relation to the risk of severe post-operative complications, in the same way as for moderate complications, there was an increase in risk when the BMI was greater than 55. Likewise, there was no association of age greater than 40 , gender and weight above $160 \mathrm{~kg}$ with the risk of serious complications (Table 5).

TABLE 5. Risk of serious post-operative complications according to biological characteristics in 135 superobese patients submitted to FobiCapella gastric bypass surgery

\begin{tabular}{lcccc}
\hline Characteristic & With complication & Without complication & RR & CI 95\% \\
\hline $\begin{array}{l}\text { Age } \\
\quad<40 \text { years }\end{array}$ & $07(9.7 \%)$ & $65(90.3 \%)$ & 1,00 & \\
$\quad \begin{array}{l}\text { 240 years } \\
\text { Gender }\end{array}$ & $06(9.5 \%)$ & $57(90.5 \%)$ & 0,98 & $0,35-2,76$ \\
$\quad$ Male & $07(9.9 \%)$ & $64(90.1 \%)$ & 1,05 & $0,37-2,97$ \\
$\quad$ Female & $06(9.4 \%)$ & $58(90.6 \%)$ & 1,00 & \\
Weight & & & & \\
$\quad<160 \mathrm{~kg}$ & $07(9.5 \%)$ & $67(90.5 \%)$ & 1,00 & \\
$\geq 160 \mathrm{~kg}$ & $06(9.8 \%)$ & $55(90.2 \%)$ & 1,04 & $0,37-2,93$ \\
BMI & & & & \\
$<55$ & $04(5.1 \%)$ & $75(94.9 \%)$ & 1,00 & \\
$\geq 55$ & $09(16.1 \%)$ & $47(83.9 \%)$ & 3,17 & $1,03-9,80$ \\
\hline
\end{tabular}

Source: Research UFPE

Considering the co-morbidities associated and the risk of serious post-operative complications, we observed that the presence of cardiopathy/coronariopathy increased the risk of serious complications $(\mathrm{RR}=5.42)$. Other co-morbidities such as diabetes, hypertension, hypercholesterolemia, 
pneumopathy and obstructive sleep apnea did not modify the risk of the patient evolving serious post-operative complications (Table 6)

TABLE 6. Risk of serious post-operative complications according to the presence of co-morbidities in 135 superobese patients submitted to FobiCapella gastric bypass surgery

\begin{tabular}{|c|c|c|c|c|}
\hline Characteristic & With complication & Without complication & $\mathrm{RR}$ & CI 95\% \\
\hline \multicolumn{5}{|l|}{ Diabetes } \\
\hline Yes & $04(11.8 \%)$ & $30(88.2 \%)$ & 1,31 & $0,43-$ \\
\hline No & $09(9.0 \%)$ & $91(91.0 \%)$ & 1,00 & 3,97 \\
\hline \multicolumn{5}{|l|}{ Hypertension } \\
\hline Yes & $10(11.0 \%)$ & $81(89.0 \%)$ & 1,58 & $0,46-$ \\
\hline No & $03(7.0 \%)$ & $40(93.0 \%)$ & 1,00 & 5,43 \\
\hline \multicolumn{5}{|c|}{ Hypercholesterolemia } \\
\hline Yes & $03(15.8 \%)$ & $16(84.2 \%)$ & 1,82 & \multirow{2}{*}{$0,55-6,0$} \\
\hline No & $10(8.7 \%)$ & $105(91.3 \%)$ & 1,00 & \\
\hline \multicolumn{5}{|l|}{ Cardio/ } \\
\hline coronariopathy & $01(50.0 \%)$ & $01(50.0 \%)$ & 5,42 & $1,22-$ \\
\hline $\begin{array}{l}\text { Yes } \\
\text { No }\end{array}$ & $12(9.2 \%)$ & $118(90.8 \%)$ & 1,00 & 24,0 \\
\hline \multicolumn{5}{|l|}{ Pneumopathy } \\
\hline Yes & $05(11.4 \%)$ & $39(88.6 \%)$ & 1,25 & $0,43-$ \\
\hline No & $08(9.1 \%)$ & $80(90.9 \%)$ & 1,00 & 3,60 \\
\hline \multicolumn{5}{|l|}{ Sleep apnea } \\
\hline Yes & $04(12.1 \%)$ & $29(87.9 \%)$ & 1,36 & $0,45-$ \\
\hline No & $09(8.9 \%)$ & $92(91.1 \%)$ & 1,00 & 4,13 \\
\hline \multicolumn{5}{|l|}{ Any co-morbidity } \\
\hline Yes & $13(10.8 \%)$ & $107(89.2 \%)$ & & - \\
\hline No & $0(0.0 \%)$ & $15(100.0 \%)$ & - & $P=0,18$ \\
\hline
\end{tabular}

Source: Research UFPE

When the characteristics of the patients were evaluated in relation to the risk of death, there was no relationship between age greater than 40, gender or weight above $160 \mathrm{~kg}$. However, $\mathrm{BMI} \geq 55$ was strongly associated with the risk of death $(P<0,007)$ (Table 7).

TABLE 7. Risk of post-operative death according to biological characteristics in 135 superobese patients submitted to Fobi-Capella gastric bypass surgery

\begin{tabular}{|c|c|c|c|c|}
\hline \multirow{2}{*}{ Characteristic } & \multicolumn{2}{|c|}{ Death } & \multirow{2}{*}{$\mathrm{RR}$} & \multirow{2}{*}{ CI $95 \%$} \\
\hline & Yes & No & & \\
\hline \multicolumn{5}{|l|}{ Age } \\
\hline$<40$ years & $02(2.8 \%)$ & $70(97.2 \%)$ & 1,00 & $0,30-9,93$ \\
\hline$\geq 40$ years & $03(4.8 \%)$ & $60(95.2 \%)$ & 1,71 & \\
\hline \multicolumn{5}{|l|}{ Gender } \\
\hline Male & $04(5.6 \%)$ & $67(94.4 \%)$ & 3,61 & $0,41-31,42$ \\
\hline Female & $01(1.6 \%)$ & $63(98.4 \%)$ & 1,00 & \\
\hline \multicolumn{5}{|l|}{ Weight } \\
\hline$<160 \mathrm{~kg}$ & $02(2.7 \%)$ & $72(97.3 \%)$ & 1,00 & $0,31-10,54$ \\
\hline$\geq 160 \mathrm{~kg}$ & $03(4.9 \%)$ & $58(95.1 \%)$ & 1,82 & \\
\hline \multicolumn{5}{|l|}{ BMI } \\
\hline$<55$ & $0(0.0 \%)$ & $79(100.0 \%)$ & & - \\
\hline$\geq 55$ & $05(8.9 \%)$ & $51(91.1 \%)$ & - & $P=0,007$ \\
\hline
\end{tabular}

Source: Research UFPE

Considering the co-morbidities associated with the risk of death, it may be seen that the co-morbidities, such as: diabetes, hypertension, hypercholesterolemia, pneumopathy and obstructive sleep apnea did not modify the risk of death. On the other hand, the presence of cardiopathy/coronariopathy significantly increased the risk of death by 16 times
$(R R=16.25)$. When considering the presence of any complication with the risk of death, there was no statistically significant association (Table 8).

TABLE 8. Risk of post-operative death according to the presence of comorbidities in 135 superobese patients submitted to Fobi-Capella gastric bypass surgery

\begin{tabular}{|c|c|c|c|c|}
\hline \multirow{2}{*}{ Characteristic } & \multicolumn{2}{|c|}{ Death } & \multirow{2}{*}{ RR } & \multirow{2}{*}{ CI $95 \%$} \\
\hline & Yes & No & & \\
\hline \multicolumn{5}{|l|}{ Diabetes } \\
\hline Yes & $03(8.8 \%)$ & $31(91.2 \%)$ & 4,41 & $0,77-25,30$ \\
\hline No & $02(2.0 \%)$ & $98(8.0 \%)$ & 1,00 & \\
\hline \multicolumn{5}{|l|}{ Hypertension } \\
\hline Yes & $03(3.3 \%)$ & $88(96.7 \%)$ & 0,71 & $0,12-4,10$ \\
\hline No & $02(4.7 \%)$ & $41(953 \%)$ & 1,00 & \\
\hline \multicolumn{5}{|c|}{ Hypercholesterolemia } \\
\hline Yes & $02(10.5 \%)$ & $17(89,5 \%)$ & 4,04 & $0,72-22,6$ \\
\hline No & $03(2.6 \%)$ & $112(97.4 \%)$ & 1,00 & \\
\hline \multicolumn{5}{|c|}{ Cardio/coronariopathy } \\
\hline Yes & $01(50.0 \%)$ & $01(50.0 \%)$ & 16,25 & $3,00-87,95$ \\
\hline No & $04(3.1 \%)$ & $126(96.9 \%)$ & 1,00 & \\
\hline \multicolumn{5}{|l|}{ Pneumopathy } \\
\hline Yes & $03(6.8 \%)$ & $41(93.2 \%)$ & 3,00 & $0,52-17,30$ \\
\hline No & $02(2.3 \%)$ & $86(97.7 \%)$ & 1,00 & \\
\hline \multicolumn{5}{|l|}{ Sleep apnea } \\
\hline Yes & $03(9.1 \%)$ & $30(90.9 \%)$ & 4,60 & $0,80-26,30$ \\
\hline No & $02(2.0 \%)$ & $99(98.0 \%)$ & 1,00 & \\
\hline \multicolumn{5}{|c|}{ Any co-morbidity } \\
\hline Yes & $05(4.2 \%)$ & $115(95.8 \%)$ & & - \\
\hline No & $0(0.0 \%)$ & $15(100.0 \%)$ & - & $P=0,42$ \\
\hline
\end{tabular}

When the logistic regression analysis was performed, the only characteristic that remained strongly associated to the risk of serious complications and death in the post-operative period was that of BMI (Table 9).

TABLE 9. Adjusted risk of severe post-operative complications and deaths in 135 superobese patients submitted to Fobi-Capella gastric bypass surgery

\begin{tabular}{lccccc}
\hline Variable & Coefficient & Alpha error & $\boldsymbol{P}$ & OR & CI 95\% \\
\hline BMI & 1.28 & 0.63 & 0,04 & 3,6 & $1,05-12,32$ \\
Coefficient & -2.93 & 0.51 & 0,00 & - & - \\
\hline
\end{tabular}

Source: Research UFPE

\section{DISCUSSION}

The results of the present study point to a frequency of $9.6 \%$ in severe post-operative complications and $39.3 \%$ in moderate postoperative complications in a group of superobese patients submitted to Fobi-Capella gastric bypass surgery. The death rate was 3.6\%. The major factors associated with the presence of moderate complications were BMI above 55, the presence of diabetes and obstructive sleep apnea, whilst the factors associated with serious complications and death were BMI above 55 and the presence of cardiopathy/coronariopathy. In the multivariate analysis, the only factor associated to death that remained significant was BMI above 55 .

There are relatively few studies that analyze post-operative morbidity in superobese patients, although there is evidence 
in literature that complications occur with greater frequency in these patients in relation to the severe obese ${ }^{(12)}$. The superobese group differentiates itself from all other cases of obesity as it presents greater frequency of higher surgical risk co-morbidities, greater technical difficulty (including the need for adequate equipment in the trans-operative period), high rates of complications/mortality, less weight loss after RYG bypass with a short jejunal loop (the alimentary loop used currently for these patients is a standard $150 \mathrm{~cm}$ ) and a laparosocopic RYG (RYG-LAP) being technically more difficult in this population ${ }^{(3,11,30)}$.

However, none of the studies cited above analyzed the prognostic factors for these complications within a specific population of superobese. In fact, in the majority of studies the superobese were only compared with the obese and discrepant results have been published in literature. In a recent study which analyzed 60 severe obese and 60 superobese patients submitted to RYG-LAP, the complication rates were similar in both groups ( $5 \%$ and $8 \%$, respectively), without the occurrence of a case of death ${ }^{(11)}$. However, due to the small casuistic, the power of the sample may have been insufficient to demonstrate differences that are eventually existent amongst these low frequency results.

In contrast, some studies have tried to establish the prognostic factors for post-operative complications in severely obese patients. MASON et al. ${ }^{(23)}$, in 1992, studied the peri-operative surgical risks for severe obesity and found median age, weight and BMI in the male population to be serious factors $(P<0.01)$. After logistic regression analysis, they found the greater risk of complications to be among the aged with greater BMI and of masculine gender $(P<0.01)$. The most serious risk of complications was leakage of the anastomosis, present in $0.57 \%$. The most frequent complication was respiratory, present in $4.47 \%$. Post-operative death rate was $0.1 \%$.

Recent evidence has pointed to the fact that the male severe obese in the pre-operative period present higher weight and height, higher levels of fasting glucose, glucosilate hemoglobin and triglycerides and low levels of high density lipoprotein cholesterol. Furthermore, the frequency of cardiac disease is 10 times higher and the obstructive sleep apnea is twice as much in men, which could contribute to a greater incidence of post-operative complications ${ }^{(28)}$.

NGUYEN et al. ${ }^{(24)}$, in 2003, identified age equal to or greater than 50 and male gender as being risk factors associated to post-operative complications in severely obese patients. Conversely, factors associated to greater risk of severe complications and re-operations were aged 50 and above and the experience of the surgeon. The latter also being associated to prolonged hospital stays.

LIVINGSTON et al. ${ }^{(21)}$, in 2002, also evaluated the risk factors in the pre-operative period of patients awaiting submission to RYG. They analyzed 1,067 patients of which $78 \%$ were of female gender and verified that the men were of greater height and width, as well as presenting greater frequency of co-morbidities with greater incidence of hypertension, diabetes and obstructive sleep apnea. There were 14 deaths (1.3\%), 6 because of pulmonary embolism. Approximately $67 \%$ of cases of pulmonary embolism were fatal. Anastomosis leakage occurred in $1.4 \%$ of patients, being most common in men. An analysis of logistic regression with a model that included 10 risk factors, detected that the major factors associated with post-operative morbidity were male gender and high BMI, whilst the major factor associated with mortality was age above 55 years. In the referred study, an association was described between the presence of complications and a median BMI of $55 \mathrm{~kg} / \mathrm{m}^{2}$; however a BMI cut-off point from which serious complications would occur with greater frequency was not determined contrary to the present study.

An association between the presence of diabetes and obstructive sleep apnea and higher rates of moderate complications may be explained as diabetes represents a risk factor for hospital infection and obstructive sleep apnea requires the need for prolonged intubation in the post-operative period, which increases the risk of respiratory complications.

The occurrence of leucocyte dysfunction in the obese with glucose intolerance, raising the infection rates in this group, is already a well-established fact ${ }^{(18)}$. The incidence of wound infection in surgical patients varies between $0.9 \%$ for normal patients, $2.8 \%$ for obese patients and $5 \%$ for superobese patients, not being associated with pre-operative risk or with the American Society of Anesthesiology classification ${ }^{(7)}$. Obesity has been associated with immunity suppression (immunity mediated both by cells and humoral), excess of sparsely vascularized adipose tissue, little resistance to infection and trauma caused by the clamps in the abdominal wall(13).

The association between oxygenation of the subcutaneous cellular tissue and wound infection has already been well established. A recent study compared the obese and non obese submitted to a concentration of habitual oxygen in an anesthetic and showed that the obese presented critical levels of tecidual oxigenization when compared to the non obese, which may justify the higher rate of infection at the operation site ${ }^{(17)}$.

Furthermore, other studies have demonstrated an association between immunosuppression and obesity, with Leptinproopiomeelanocortin system and high levels of $\alpha$-tumor necrosis ${ }^{(16)}$. This compromising of immunity in severelyobese patients has substantially contributed to post-operative infectious complications, which may justify the rate of infection at the operation site found in the present study $(8.1 \%)$. The use of prophylactic antibiotics and the laparoscopy should contribute to the reduction of these rates.

Contrary to this, obstructive sleep apnea contributed to the raising of post-operative morbidity because of respiratory complications. Emphasis must be made to the fact that atelectasis is common in the post-operative period, and when untreated can lead to an accumulation of secretion with posterior infection. In order to avoid pneumonia, prophylaxis of atelectasis should be carried out by pulmonary hygiene, incentive spirometry and continuous positive airway pressure in patients with obstructive sleep apnea. Such a patient 
normally presents the clinical sign of persistent fever with or without expectoration ${ }^{(13)}$.

The association of coronariopathy with serious complications and specifically with increased risk of death is justified because in reality more than a risk factor coronariopathy represented the cause of death itself. It is important to highlight that even equalized cardiopathy/coronariopathy normally represents contra-indication to obesity surgery, except in those cases in which the patient has already been submitted to an adequate correction of that base disease, for example the myocardic revascularization.

A BMI greater or equal to $55 \mathrm{~kg} / \mathrm{m}^{2}$ has been associated to a higher risk of moderate or severe complications. In addition, there is a higher risk of death when compared to the BMI $<55 \mathrm{~kg} / \mathrm{m}^{2}(P=0.007)$ group. This association persists after logistic regression. This information confirms that excess weight per se represents unequivocally the highest risk aspect for obesity surgery. Therefore, weight loss must be encouraged in the preoperative stage especially in the superobese patient group.

In final analysis, the high death and complication rates found in this study can be justified by the aspect of being from a superobese group that presents greater prevalence of co-morbidities and with lesser immune response. The real physiologic abnormalities which cause an impact on the surgical results of superobese patients is difficult to quantify.
The small series have statistical limitations while the large ones present bias in potential due to the previous selection of patients.

\section{CONCLUSION}

In the superobese preoperative evaluation, risk factors must be taken into consideration. In addition, it is recommended that co-morbidities must be treated or improved, and preliminary weight loss until an acceptable BMI level is achieved. A detailed consent form should be created for this obese group in which their real risks are clearly explained.

Any attempt to create tables of risk for the preoperative evaluation of superobese patients must be based on the evaluation of the factors associated to death and complications. BMI $\geq 55 \mathrm{~kg} / \mathrm{m}^{2}$ was the main risk factor for severe complications and death. Other risk factors affecting the outcome were diabetes, obstructive sleep apnea and cardiopathy/coronariopathy.

We believe that we have moved forward in this matter by identifying some prognostic factors for the post-operative evolution of these patients. However, new studies must be carried out to further the understanding of these factors. These studies must be longitudinals, prospectives, with a well defined selection criterion even to evaluate factors that could not be controlled in the present study.

Martins-Filho ED, Câmara-Neto JB, Ferraz AAB, Amorim M, Ferraz EM. Avaliação dos fatores de risco em pacientes superobesos submetidos a cirurgia de Fobi-Capella convencional. Arq Gastroenterol. 2008;45(1):3-10.

RESUMO - Racional - A obesidade é um dos grandes problemas de saúde mundial. A gastroplastia em Y-de-Roux é o padrão-ouro para o tratamento do obeso severo. Cirurgia em pacientes obesos tem aceitáveis índices de morbidade e mortalidade. O paciente superobeso, subgrupo de obesos graves, apresenta risco cirúrgico elevado, ainda não avaliado. Método - Foi realizado estudo retrospectivo e prospectivo envolvendo 135 pacientes superobesos submetidos a gastroplastia em Y-de-Roux para tratamento de obesidade severa no Hospital das Clínicas da Universidade Federal de Pernambuco, Recife, PE, no período de novembro de 1997 até setembro de 2003. As variáveis independentes foram possíveis fatores de risco: idade, sexo, peso, índice de massa corpórea, diabetes, hipertensão, hipercolesterolemia, apnéia do sono, cardiopatia/coronariopatia, pneumopatia ou qualquer outra co-morbidade. As variáveis dependentes foram as complicações graves, complicações leves e óbito. Resultados - Diabetes $(R R=1.6$ and $C I=1.02-2.40)$ e apnéia do sono $(R R=1.8$ and $C I=1.18-2.64)$ foram associados a complicações leves. Cardiopatia/coronariopatia foram associadas a complicações graves $(R R=5.42$ and $C I=1.22-2.40)$ e óbito $(R R=16.25$ and $C I=3.00-87.95)$. Índice de massa corporal $\geq 55 \mathrm{~kg} / \mathrm{m}^{2}$ foi associado a complicações leves ( $R R=1.58$ and $C I=1.04-2.40)$, complicações graves ( $R R=3.17$ and $C I=1.03-9.80)$ e óbito. Após regressão logística, o índice de massa corporal $\geq 55 \mathrm{~kg} / \mathrm{m}^{2}$ permaneceu como forte fator de risco para óbito $(\mathrm{OR}=3.6$ and $\mathrm{CI}=1.05-12.32)$. Conclus ão $-\mathrm{O}$ índice de massa corporal $\geq 55 \mathrm{~kg} / \mathrm{m}^{2}$ foi o principal fator de risco para complicações severas e óbito. Outros fatores de risco que afetaram os resultados foram: diabetes, apnéia do sono e cardiopatia/coronariopatia.

DESCRITORES - Obesidade mórbida. Cirurgia bariátrica. Fatores de risco. Complicações pós-operatórias. 


\section{REFERENCES}

1. Allison DB, Fontaine KR, Manson JE, Stevens J, VanItallie TB. Annual deaths attributable to obesity in the United States. JAMA. 1999;282:1530-8.

2. Benotti PN, Forse RA. The role of gastric surgery in the multidisciplinary management of severe obesity. Am J Surg. 1995;169:361-7.

3. Brolin RE, Kenler HA, Gorman JH, Cody RP. Long-limb gastric bypass in the superobese. A prospective randomized study. Ann Surg. 1992;215:387-95.

4. Brolin RE, LaMarca LB, Kelner HA, Cody RP. Malabsorptive gastric bypass in pacients with superobesity. J Gastrointest Surg. 2002;6:195-203 - discusion 204-5.

5. Capella RF, Capella JF, Mandec H, Nath P. Vertical banded gastroplasty - gastric bypass: preliminary report. Obes Surg. 1991;1:389-95.

6. Capella RF, Capella JF. An assessment of vertical banded gastroplasty-Roux-en-Y gastric bypass for the treatment of morbid obesity. Am J Surg. 2002;183:117-23.

7. Choban PS, Heckler R, Burge JC, Flancbaum L. Increased incidence of nosocomial infections in obese surgical patients. Am Surg. 1995;61:1001-5.

8. Coutinho FW, Benchimol AK. Obesidade mórbida e afecções associadas. In: Garrido Jr AB, Ferraz EM, Barroso FL, Marquesini JB, Szego T, editors. Cirurgia da obesidade. São Paulo: Atheneu; 2003. p.13-7.

9. Deitel M. Overweight and obesity worldwide now estimated to involve 1.7 billion people. Obes Surg. 2003;13:329-30.

10. Drenick EJ, Bale GS, Seltzer F, Johnson DG. Excessive mortality and causes of death in morbidly obese men. JAMA. 1980;243:443-5.

11. Dresel A, Kuhn JA, McCarty TM. Laparoscopic Roux-en-Y gastric bypass in morbidly obsese and super morbidly obese patients. Am J Surg. 2004;187:230-2.

12. Ferraz EM, Arruda PCL, Ferraz AAB, Bacelar TS, Albuquerque AC. Severe obese patients have a low incidence of operative mortality? The Recife score: a new morbidity and mortality grading scale. A preliminary report. VII World Congress of Bariatric Surgery, 2002.

13. Ferraz EM, Martins EDF. Infecção em cirurgia bariátrica. In: Garrido Jr AB, editor. Cirurgia da obesidade. São Paulo: Atheneu; 2003. p.105-11.

14. Fisher BL, Schauer P. Medical and surgical options in the treatment of severe obesity. Am J Surg. 2002;184:9-16.

15. Fobi MAL, Lee H, Flemming A. The surgical technique of the banded Roux-in-Y gastric bypass. J Obes Weight Reg. 1989;8:99-103.

16. Hotamisligil GS, Arner P, Caro JF, Atkinson RL, Spiegelman BM. Increased adipose tissue expression of tumor necrosis factor-alpha in human obesity and insulin resistance. Clin Invest. 1995;95:2409-15.

17. Kabon B, Nagele A, Reddy D, Eagon C, Fleshman JW, Sessler DI, Kurz A Obesity decreases perioperative tissue oxygenation. Anesthesiology. 2004;100: 274-80.
18. Kolterman OG, Olefsky JM, Kurahara C, Taylor K. A defect in cell-mediated immune function in insulin-resistant diabetic and obese subjects. J Lab Clin Med. 1980;96:535-43.

19. Kral JG. Morbidity of severe obesity. Surg Clin North Am. 2001;81:1039-61.

20. Lévy E, Lévy P, Le Pen C, Basdevant A. The economic cost of obesity: the French situation. Int J Obes Relat Metab Disord. 1995;19:788-92.

21. Livingston EH, Huerta S, Arthur D, Lee S, De Shields S, Heber D. Male gender is a predictor of morbidity and age a predictor of mortality for patients undergoing gastric bypass surgery. Ann Surg. 2002;236:576-82.

22. Mason EE, Priten KJ, Barron P. Risk reduction in gastric operations for obesity. Ann Surg. 1979;190:158-65.

23. Mason EE, Renquist KE, Jiang D. Perioperative risks and safety of surgery for severe obesity. Am J Clin Nutr. 1992;55:573-6.

24. Nguyen NT, Rivers R, Wolfe BM. Factors associated with operative outcomes in laparoscopic gastric bypass. J Am Coll Surg. 2003;197:548-55.

25. NIH Consensus Development Conference. Health implications of obesity. Ann Intern Med. 1985;103:977-1077.

26. NIH Consensus Development Program. Gastrointestinal surgery for severe obesity. In: NIH Consensus Statement. 1991;9:1-20.

27. Pasulka PS, Bistrian BR, Benotti PN, Blackburn GL. The risks of surgery in obese patients. Ann Intern Med. 1986;104:540-6.

28. Residori L, García-Lorda P, Flancbaum L, Pi-Sunyer FX, Laferrere B. Prevalence of co-morbidities in obese patients before bariatric surgery: effect of race. Obes Surg. 2003;13:333-40.

29. Rosenbaum M, Leibel RL, Hirsch J. Medical progress: obesity. N Eng J Med. 1997;337:396-405

30. See C, Carter PL, Elliott D, Mullenix P, Eggebroten W, Porter C, Watts D. An institutional experience with laparoscopic gastric bypass complications seen in the first year compared with open gastric bypass complications during the same period. Am J Surg. 2002;183:533-8.

31. Sjostrom CD. Surgery as an intervention for obesity. Results from Swedish obese subjects study. Growth Horm IGF Res. 2003;13 (Suppl A):22-6.

32. Sjostrom LV. Morbidity of severily obese subjects. Am J Clin Nutr. 1992;55:508-15.

33. Stallone DD. The influence of obesity and its treatment on the immune system. Nutr Rev. 1994;52:37-50.

34. Sugerman HJ, Kellum JM, Engle KM, Wolfe L, Starkey JV, Birkenhauer R, Fletcher P, Sawyer MJ. Gastric bypass for treating severe obesity. Am J Clin Nutr. 1992;55:560s-6s. 